Sains Malaysiana 48(2)(2019): 301-307

http://dx.doi.org/10.17576/jsm-2019-4802-05

\title{
Effects of N-Methyl-N-Nitrosourea on Seed Germination of Stevia rebaudiana
}

(Kesan N-Metil-N-Nitrosourea pada Percambahan Biji Benih Stevia rebaudiana)

\author{
Lyena WATTY ZURAINE AHMAD, ZARINA ZAINUDDIN*, MOHAMAD OSMAN, \\ AZHAR MOHAMAD \& NORRIZAH JAAFAR SIDIK
}

\begin{abstract}
Stevia rebaudiana is a unique plant that contains non-caloric natural sweetener and has gained much interest among Malaysians. In this study, the effect of different concentrations of $N$-methyl-N-nitrosourea (MNU) was assessed in inducing mutation in Stevia seeds to produce genetic variations, which is valuable for crop improvement. Stevia seeds were soaked in six concentrations of $M N U(0.0,0.13,0.25,0.38,0.50$, and $1.00 \mathrm{mM})$ for four different durations $(15,30,45$, and 60 $\mathrm{min}$ ) at room temperature. As a result, application of $M N U$ reduced the germination percentage and germination rate of Stevia seeds as compared to the control group. Prolonged exposure to the highest concentration of MNU recorded the lowest percentage of germination $(2.5 \pm 1.4 \%)$ and the lowest germination rate $(0.21 \pm 0.16)$. Tricots were observed among seedlings treated with 0.13,0.38 and $1.0 \mathrm{mM}$ of MNU for $30 \mathrm{~min}$. Presence of seedlings with albino colour proved the mutagenic effect of MNU on Stevia genome. Based on the percentage of seedlings with chlorophyll mutation, the most effective and efficient mutagenic treatment to induce mutation was $60 \mathrm{~min}$ in $0.25 \mathrm{mM}$ of $\mathrm{MNU}$.
\end{abstract}

Keywords: Germination; MNU; mutagenic effectiveness; mutagenic efficiency; Stevia rebaudiana

ABSTRAK

Stevia rebaudiana ialah tumbuhan unik yang mengandungi pemanis semula jadi tanpa kalori yang menarik minat ramai rakyat Malaysia. Dalam kajian ini, kesan kepekatan N-metil-N-nitrosourea (MNU) dikaji dalam mendorong mutasi pada biji Stevia untuk menghasilkan variasi genetik yang berguna untuk pembaikan tanaman. Biji Stevia direndam dalam larutan MNU dengan enam kepekataan berlainan $(0.0,0.13,0.25,0.38,0.50$ dan $1.00 \mathrm{mM})$ untuk empat tempoh yang berbeza (15, 30, 45 dan 60 minit) pada suhu bilik. Penggunaan MNU didapati mengurangkan peratus dan kadar percambahan biji Stevia berbanding dengan kumpulan kawalan. Pendedahan berpanjangan kepada kepekatan MNU yang tertinggi mencatatkan peratusan percambahan terendah $(2.5 \pm 1.4 \%)$ dan kadar percambahan terendah $(0.21 \pm$ 0.16). Anak benih dengan trikot dicerap pada kumpulan yang dirawat dengan 0.13, 0.38 dan $1.0 \mathrm{mM} \mathrm{MNU}$ selama 30 minit. Kehadiran anak benih dengan warna albino membuktikan kesan mutagen MNU pada genom Stevia. Berdasarkan peratusan anak benih dengan mutasi klorofil, rawatan mutagenik yang paling berkesan dan cekap untuk merangsang mutasi ialah selama 60 minit dalam $0.25 \mathrm{mM}$ MNU.

Kata kunci: MNU; mutagenik berkesan; mutagenik cekap; percambahan; Stevia rebaudiana

\section{INTRODUCTION}

Stevia rebaudiana Bert. is a plant that produces non-caloric natural sweetener. A native plant of Paraguay, this member of Asteraceae family is a shrubby plant with an alternate leaf arrangement and small white flowers arranged in an irregular cyme (Brandle et al. 1998). The flower contains 5 to 6 seeds with two different colours, black (viable) and tan (non-viable). The seeds are contained in $3 \mathrm{~mm}$ length of achenes, which has 20 persistent pappus bristles (Goettemoeller \& Ching 1999).

The Stevia plant contains a complex mixture of labdane, diterpenes, triterpenes, stigmasterol, tannins, volatile oils and nine types of glycoside named stevioside, steviobioside, dulcoside, and rebaudiosides A, B, C, D, E and $F$ (Geuns 2003). Stevioside and rebaudioside A are the most abundant substances in Stevia (Cramer \& Ikan 1987). Stevia derives its sweetness from stevioside (Singh
\& Rao 2005). Widely used as a sweetener, the stevioside extract from the leaves tastes 300 times sweeter than sugar (Schwontkowski 1993). No calory is absorbed by the body from Stevia as the sweet glycosides of Stevia are not recognised by the system in the human body, causing them to pass right through the excretion channel; therefore, it is suitable for diabetic and hypoglycemic patients (Geuns 2003). Studies have shown that stevioside is nontoxic, nonmutagenic, and noncarcinogenic in various mammalian species (Toskulkao et al. 1997; Xili et al. 1992).

Breeding efforts and improvement programmes on Stevia have been conducted in Malaysia with an objective to find a suitable variety with high stevioside contents that can adapt to the Malaysia short daylength condition (Mohamad et al. 2012; Tan et al. 2008). Use of chemicals as a mutation agent or mutagen has been proven to produce genetic variability for plant improvement 
purposes. Some of the common chemical mutagens are ethyl methane sulphonate (EMS) (Alcantara et al. 1996; Begum \& Dasgupta 2010; Kumar \& Yadav 2010) and colchicine (Luckett 1989; Zulkarnain 2004). In Malaysia, colchicine has been used to induce poliploidy in Stevia (Mohamad et al. 2012). However, very little study has been carried out on mutation induction of Stevia involving $N$-methyl- $N$-nitrosourea (MNU). MNU, with a molecular formula of $\mathrm{C}_{2} \mathrm{H}_{5} \mathrm{~N}_{3} \mathrm{O}_{2}$, has carcinogenic and mutagenic properties, which come from the nitroso compounds such as nitrosamides, nitrosamidines, and nitrosamines (Satoh et al. 2010). Comparing to animals, there are fewer studies on the mutagenic effects of MNU on plants (Kurowska et al. 2012). MNU has been used in breeding program of rice (Satoh et al. 2010), barley (Jovtcher et al. 2001), soybean (Hoffman et al. 1999; Hudson 2012; Sebastian et al. 1989) and wheat (Desai \& Bhatia 1975). MNU is considered to be less harmful towards plant breeders because it is easily degraded once exposed to sunlight. However, further precaution needs to be taken as alkylating agents are known to cause DNA lesion (Leitao 2012). Therefore, this study was aimed to assess the effect of different concentrations of $\mathrm{N}$-methyl- $\mathrm{N}$-nitrosourea (MNU) on seed germination of Stevia.

\section{MATERIALS AND METHODS}

\section{MNU TREATMENT OF SEEDS}

Seeds were harvested from healthy Stevia rebaudiana plants of accession MS012. The viable and non-viable seeds were separated manually based on the colour of the seeds. Seeds were immersed for 15, 30, 45, and $60 \mathrm{~min}$ in six groups of MNU concentrations at $0.0,0.13,0.25,0.38$, 0.50 , and $1.00 \mathrm{mM}$ in a dimly lit room. The experiment was conducted in four replicates with 50 seeds each. After treatment with MNU, the seeds were dried before the germination step.

\section{SEED GERMINATION}

All treated seeds were allowed to germinate on peat moss as the planting media and covered with a transparent domeshaped plastic cover. Germination process took place in a room $\left(25^{\circ} \mathrm{C}\right)$ and all the seeds were placed $30 \mathrm{~cm}$ under two red fluorescent tubes (wavelength $660 \mathrm{~nm}$ ) to increase germination rate (Abdullateef et al. 2015). The red light exposure was maintained for $14 \mathrm{~h}$. The germination was observed for 20 days. The germination percentage (GP) and germination rate (GR) of each treatment were determined. Germination percentage (GP) and germination rate (GR) were calculated as follows (Awasthi et al. 2016):

$$
\mathrm{GP}=\frac{\text { Number of total germinated seeds }}{\text { Total number of seed tested }} \times 100
$$

$\underline{\text { Number of germinated seeds }}+\ldots+$ Number of germinated seeds

\section{MORPHOLOGICAL OBSERVATION}

The number of cotyledons and chlorophyll mutation of cotyledons of the progenies produced were observed and recorded. Based on the percentages of chlorophyll mutation, the mutagenic effectiveness and efficiency were determined using the formula below (Bashir et al. 2013):

$$
\begin{gathered}
\text { Effectiveness }=\frac{\text { Seedling with chlorophyll mutation }(\%)}{(\text { Concentration of MNU)(Duration of treatment })} \times 100 \\
\text { Efficiency }=\frac{\text { Seedling with chlorophyll mutation }(\%)}{\text { Non-germinated seedling }(\%)} \\
\text { STATISTICAL ANALYSIS }
\end{gathered}
$$

A factorial design $(4 \times 6)$ was conducted to compare the effects of time of treatments and the interaction between concentrations of MNU on Stevia germination. The germination percentage and rate were subjected to two-way ANOVA with pairwise comparisons for statistical analysis with $p$-value 0.05 , using SPSS Statistics 22 . As for cotyledon observations (number and colour), results were presented as percent of the total.

\section{RESULTS AND DISCUSSION}

\section{PERCENTAGE OF GERMINATION}

Seeds of Stevia started to germinate around the $3^{\text {rd }}$ day after sowing. Two-way ANOVA was conducted to examine the effect of time of treatment and concentration of MNU on the percentage of germination. There was a statistically significant interaction between both factors on the percentage of germination with p-value less than $0.05(\mathrm{~F}=12.107)$. The percentages of germination for different concentrations of MNU were grouped into four different times of exposure, namely, 15, 30, 45 and 60 min (Figure 1). For 15 min soaking time, the highest germination percentage was for the control ( $0.0 \mathrm{mM}$ MNU) with $26.0 \pm 1.4 \%$ followed by treatment with $0.13 \mathrm{mM}$ MNU $(21.0 \pm 1.4 \%)$. Meanwhile, treatment with the highest concentration of MNU recorded the lowest germination percentage with $7.0 \pm 1.4 \%$. In line with previous studies that used MNU on rice seeds, the germination percentage decreased when the concentration of MNU increased (Satoh \& Omura 1979). Based on ANOVA, there was a significant difference in germination percentage between untreated seeds and treated seeds.

For seeds soaked with MNU for $30 \mathrm{~min}$, the highest germination percentage was obtained from $0.0 \mathrm{mM}$ MNU $(33.0 \pm 1.4 \%)$ and the lowest germination percentage was from $1.0 \mathrm{mM}(11.5 \pm 1.4 \%)$. ANOVA and post-hoc Tukey's test showed that the control was significantly different from all other concentrations except for $0.13 \mathrm{mM}$ MNU. The highest percentage of germination for seeds soaked for 45 min was from untreated seeds $(33.0 \pm 1.4 \%)$, followed by $0.13 \mathrm{mM}$ with $28.0 \pm 1.4 \%$. The lowest percentage was obtained from $1.0 \mathrm{mM}$ MNU $(5.0 \pm 1.4 \%)$ (Figure 1). There 


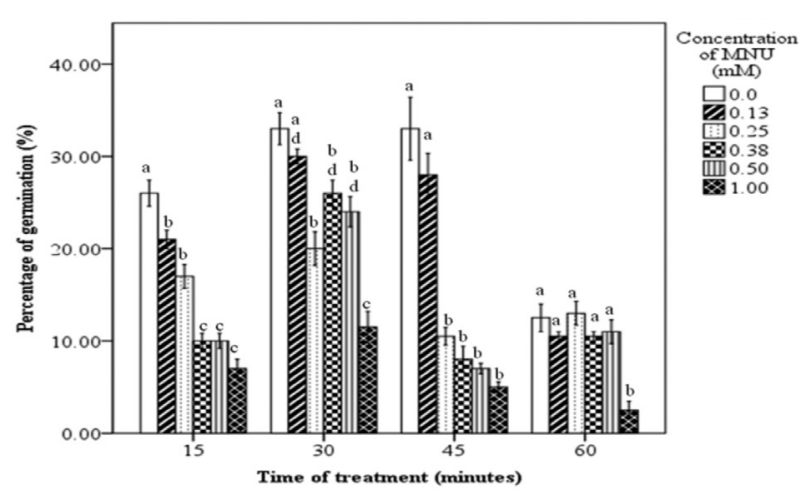

FIGURE 1. Percentage of Stevia rebaudiana germination (mean \pm SE) for different times of treatments and concentrations of MNU (same alphabets denote no significant difference at $p>0.05$ for each group of treatment)

was no significant difference of germination percentage between untreated seeds and seeds treated with $0.13 \mathrm{mM}$ MNU as suggested by ANOVA Tukey's test, but there was a significant difference between these two concentrations with the last four concentrations: $0.25,0.38,0.50$, and 1.00 $\mathrm{mM}$ MNU. For all seeds treated with MNU for $60 \mathrm{~min}$, the highest percentage was $13.0 \pm 1.4 \%$ for treatment with 0.25 $\mathrm{mM}$ MNU, which was slightly higher than the percentage of untreated seeds $(12.5 \pm .4 \%)$. Meanwhile, seeds treated with the highest concentration of MNU gave the lowest percentage of germination among all treatments with 2.5 $\pm 1.4 \%$.

Seed germination is usually used as a parameter to estimate the biological damage done by mutagens (Songsri et al. 2011; Ramchander et al. 2015; Ravichandran \& Jayakumar 2014). Any effects in germination can be considered as an indication of the mutagenic effects (Gaul 1970). In the present study, the germination percentage was found to be greatly affected by mutagen. In line with a previous study (Goettemoeller \& Ching 1999), Stevia indeed has a very low percentage of germination. Only around $30 \%$ of untreated seeds germinated. This number declined drastically when the seeds were treated with mutagen.

Overall, $1.0 \mathrm{mM}$ of MNU concentration reduced the percentage of germination as compared to control treatment. A decrease in the percentage of germination at higher doses of mutagens may also be attributed to disturbances at the cellular level including chromosomal damages (Khan \& Tyagi 2010). MNU dose-dependent inhibition of DNA synthesis was observed in the individual meristem of barley based on the low frequency of S-phase in the cell embryo (Fousová et al. 1974). MNU is known to induce mutation by changing the GC bases to AT bases which might affect the ability of the seed to grow (Satoh et al. 2010).

\section{GERMINATION RATE}

The germination rate was determined based on the number of germinated seeds per day. Based on two-way ANOVA, germination rate was affected significantly by two factors involved time of treatment and concentration of MNU with p-value less than $0.05(\mathrm{~F}=14.923)$.

For exposure time of $15 \mathrm{~min}$ (Figure 2), there was a decrease in the germination rate when the concentrations increased from $0.1 \mathrm{mM}(3.23 \pm 0.16)$ to $1.0 \mathrm{mM}(0.96 \pm$ $0.16)$. ANOVA and Tukey's test suggested that there was a significant difference of the germination rate for the control compared to all other concentrations as revealed by $p$-value, 0.05 . For 30 and 45 min exposure time, there was a fluctuation in germination rate. For seeds soaked for 30 min, initially the germination rate decreased significantly when the concentration of MNU increased from $0.0 \mathrm{mM}$ $(3.33 \pm 0.16)$ to $0.25 \mathrm{mM}(1.56 \pm 0.16)$. The germination rate showed no signicant difference with control group when concentration increased from 0.38 to $0.50 \mathrm{mM}$ MNU with values at $3.08 \pm 0.16$ and $2.98 \pm 0.16$, respectively. When the concentration was increased to $1.0 \mathrm{mM}$, the germination rate dropped drastically to $0.87 \pm 0.16$. In 45 min exposure time, the germination rate topped the chart with $3.35 \pm 0.16$ for the control and continued to drop to $0.60 \pm 0.16$ when treated with $0.38 \mathrm{mM}$ MNU. Then the germination rate increased slightly to $0.96 \pm 0.16$ when soaked in $0.50 \mathrm{mM}$ MNU solution and dropped again to $0.83 \pm 0.16$ when treated with the highest concentration of MNU (1.0 mM).

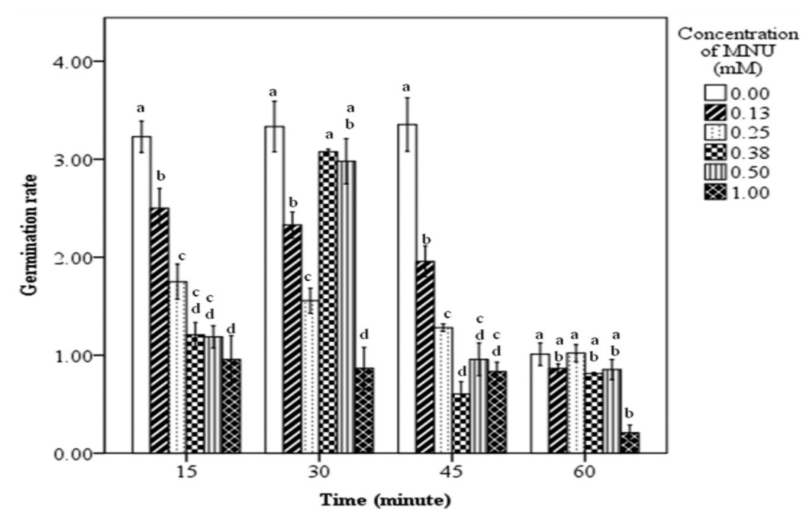

FIGURE 2. Germination rate of Stevia rebaudiana (mean $\pm \mathrm{SE}$ ) for different times of treatments and concentrations of MNU (same alphabets denote no significant difference at $p>0.05$ for each group of treatment)

Meanwhile, for 60 min of exposure time, the quality of seeds was not as good as other batches, which was shown by low germination rate for control group $(1.01 \pm 0.16)$. Overall, the germination rate fluctuated, with a slight drop for $0.13 \mathrm{mM}$ at $0.86 \pm 0.16$ as compared to the control group. Then, in $0.25 \mathrm{mM}$, the germination rate increased to $1.02 \pm 0.16$ and dropped again for $0.38 \mathrm{mM}$ at $0.81 \pm$ 0.16 . However, the germination rate increased back to 0.85 \pm 0.16 when seeds were treated with $0.50 \mathrm{mM}$ MNU. When the concentration of $\mathrm{MNU}$ was increased to $1.0 \mathrm{mM}$, the germination rate dropped drastically to $0.21 \pm 0.16$. Despite 
the fluctuation, the germination rate for treatments with $0.13,0.25,0.38$, and $0.50 \mathrm{mM}$ MNU was not significantly different to the control except for the highest concentration of MNU.

In general, the germination rate decreased when the concentration of MNU increased. Application of MNU on seeds of Stevia might affect the cell division process. MNU is known to affect the $\mathrm{G}_{1}$ phase of cell cycle in rat meiotic cell cycle (Kallio \& Lahdetie 1995). The $\mathrm{G}_{1}$ phase is the first checkpoint for cells to resume cell cycle, which is crucial for the plant embryo cells to continue growing for seedling development (Barrôco et al. 2005). Any interruption in this phase might cause cell arrest, as most of the meristematic cells of dry seeds have mostly a $\mathrm{G}_{1}-$ phase DNA content (Vázquez-Ramos \& de la Paz Sánchez 2003).

\section{NUMBER OF COTYLEDONS}

Being a dicotyledonous plant, typically Stevia possesses two embryonic leaves (dicots). An observation was done to see any effect of MNU treatments on the cotyledons of Stevia. Table 1 displays the number of seedlings which emerged with three cotyledons (tricots) after treatment with MNU. Among all the treatments, only seeds soaked with MNU for 30 min produced seedlings with unusual numbers of cotyledons, which can be seen in MNU treatment of 0.13 $\mathrm{mM}(1.67 \%)$ (Figure 3), $0.38 \mathrm{mM}(3.84 \%)$ and $1.0 \mathrm{mM}$ $(4.54 \%)$.

Cotyledons provide nutrient to the growing seedling before it can perform photosynthesis to make its own food. The presence of three cotyledons in seedlings indicates the early sign of shoot apical meristem malfunction (Para \& Sundås-Larsson 2003). Studies on the tricotyledonous mutant in Catharanthus roseus suggested that this phenotype might be controlled by a single recessive gene (Rai \& Kumar 2001).

\section{CHLOROPHYLL MUTATION}

Table 2 shows the percentages of seedlings with chlorophyll mutation. There was only one type of chlorophyll mutation observed which was albino, where the cotyledons were pale yellow in colour (Kozgar 2014). The treatment of 30 min with MNU provided more responses, which can be seen in concentrations of $0.38,0.5$, and $1.0 \mathrm{mM}$ (Table 2). The same observations were also observed with $0.38 \mathrm{mM}$ MNU (soaked for $45 \mathrm{~min}$ ) and in $0.25 \mathrm{mM}$ MNU (soaked for $60 \mathrm{~min}$ ) with the percentage of the former was $10 \%$ and the latter was $20 \%$, which was the highest percentage of seedling with albino cotyledons. Overall, seeds treated in any concentrations of MNU for $15 \mathrm{~min}$ did not produce

TABLE 1. Percentage of Stevia rebaudiana seedlings with three cotyledons (tricots) after MNU treatments

\begin{tabular}{ccccc}
\hline & \multicolumn{4}{c}{ Percentages of tricots $(\%)$} \\
\hline Concentration of MNU $(\mathrm{mM})$ & $15 \mathrm{~min}$ & $30 \mathrm{~min}$ & $45 \mathrm{~min}$ & $60 \mathrm{~min}$ \\
\hline Control & 0 & 0 & 0 & 0 \\
0.13 & 0 & 1.67 & 0 & 0 \\
0.25 & 0 & 0 & 0 & 0 \\
0.38 & 0 & 3.84 & 0 & 0 \\
0.50 & 0 & 0 & 0 & 0 \\
1.00 & 0 & 4.54 & 0 & 0 \\
\hline
\end{tabular}

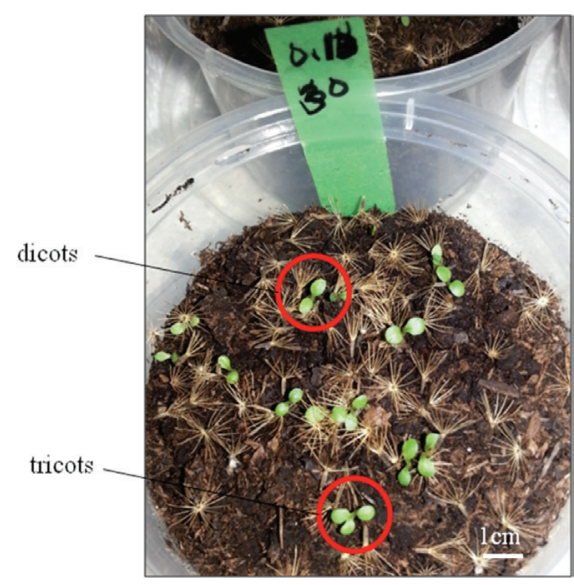

FIGURE 3. Treatment with $0.13 \mathrm{mM}$ MNU for 30 min produces Stevia rebaudiana seedlings with 2 (dicots) and 3 (tricots) embryonic leaves 
TABLE 2. Percentage of Stevia rebaudiana seedlings with chlorophyll mutation after MNU treatments

\begin{tabular}{ccccc}
\hline & \multicolumn{4}{c}{ Percentages of chlorophyll mutation (\%) } \\
\hline Concentration of MNU (mM) & 15 min & 30 min & 45 min & 60 min \\
\hline Control & 0 & 0 & 0 & 0 \\
0.13 & 0 & 0 & 0 & 0 \\
0.25 & 0 & 0 & 0 & 20.0 \\
0.38 & 0 & 3.85 & 10.0 & 0 \\
0.5 & 0 & 2.63 & 0 & 0 \\
1.0 & 0 & 4.54 & 0 & 0 \\
\hline
\end{tabular}

any seedling with albino colouration. Presence of seedlings with albino cotyledons could be due to the mutation of phytochrome A (phyA) (Hofmann 2009).

\section{MUTAGENIC EFFECTIVENESS AND EFFICIENCY}

The usefulness of mutagens can be measured through their effectiveness and efficiency (Kozgar 2014). Mutagenic effectiveness can be defined as a measure of the mutations induced per unit dose or concentration of a mutagen. Meanwhile, mutagenic efficiency gives an idea of the genetic damage or mutation that occurred in relation to the total damage in a treated plant. The mutagenic effectiveness and efficiency of MNU to induce mutation in Stevia at different concentrations and durations of treatment were determined based on the number of seedlings with albino cotyledons. As shown in Table 3 , the most effective and efficient mutagenic group of treatment was $60 \mathrm{~min}$ in $0.25 \mathrm{mM}$ MNU. Being effective and efficient mutagen at the same time have not always been the case, as discussed by Kozgar (2014). There were cases where lower and moderate doses of mutagens showed higher effectiveness and efficiency. Having these two properties will ensure the probability to recover potential mutation at higher frequency.

For practical purposes, identifying threshold dose or concentration of a mutagen is important in order to increase the genetic variability and number of useful mutants. Therefore, the aim is to obtain high efficiency which can be identified based on number of chlorophyll mutation. Even though chlorophyll mutation frequency usually increased with increase in mutagen's concentration, any increment of mutagen's concentration might not increase the frequency of mutant when the mutagen reaches the saturation point (Srivinas \& Veerabadhiran 2010).

\section{CONCLUSION}

Seeds of Stevia were affected by the mutagenic properties of MNU, which were demonstrated by low percentage of germination and germination rate as compared to the control treatment. MNU treatment also affected cotyledon formation and chlorophyll production in some of the Stevia seedlings, where some seedlings produced three cotyledons and some were pale yellow in colour or albino. Based on the percentage of chlorophyll mutation, treatment of MNU with concentration $0.25 \mathrm{mM}$ at $60 \mathrm{~min}$ was found to be the most effective and efficient to induce mutation in Stevia. Novel approaches to induce mutation in Stevia using MNU will hasten the breeding efforts and improvement programmes on Stevia in Malaysia with an objective to find the suitable variety that can adapt to the unique growing conditions in Malaysia.

TABLE 3. Mutagenic effectiveness and efficiency for different groups of MNU treatment on Stevia rebaudiana

\begin{tabular}{|c|c|c|c|c|c|}
\hline \multirow[b]{2}{*}{$\begin{array}{l}\text { Concentration } \\
\text { of MNU (mM) }\end{array}$} & \multicolumn{5}{|c|}{ Mutagenic effectiveness and efficiency } \\
\hline & & $15 \min$ & $30 \mathrm{~min}$ & $45 \mathrm{~min}$ & $60 \mathrm{~min}$ \\
\hline \multirow{2}{*}{0.13} & Effectiveness & 0 & 0 & 0 & 0 \\
\hline & Efficiency & 0 & 0 & 0 & 0 \\
\hline \multirow{2}{*}{0.25} & Effectiveness & 0 & 0 & 0 & 1.33 \\
\hline & Efficiency & 0 & 0 & 0 & 0.23 \\
\hline \multirow{2}{*}{0.38} & Effectiveness & 0 & 0.34 & 0.58 & 0 \\
\hline & Efficiency & 0 & 0.05 & 0.11 & 0 \\
\hline \multirow{2}{*}{0.5} & Effectiveness & 0 & 0.17 & 0 & 0 \\
\hline & Efficiency & 0 & 0.03 & 0 & 0 \\
\hline \multirow{2}{*}{1.0} & Effectiveness & 0 & 0.15 & 0 & 0 \\
\hline & Efficiency & 0 & 0.05 & 0 & 0 \\
\hline
\end{tabular}




\section{ACKNOWLEDGEMENTS}

We would like to show our gratitude to all the people involved, especially Ms. Fatin Hilyani and Mr. Amri for their assistance in lab works during the course of this research.

\section{REFERENCES}

Abdullateef, R.A., Mohamad, O.\& Zarina,Z.2015. Acclimatized apparatus enhanced seed germination in Stevia rebaudiana Bertoni. International Journal of Biology 7(2): 28-34.

Alcantara, T.P., Bosland, P.W. \& Smith, D.W. 1996. Ethyl methane sulphonate induced seed mutagenesis of Capsicum annuum. Journal of Heredity 87(3): 239-241.

Awasthi, P., Karki, H., Vibhuti, Bargali, K. \& Bargali, S.S. 2016. Germination and seedling growth of pulse crop (Vigna spp.) as affected by soil salt stress. Current Agricultural Research Journal 4(2): 159-170.

Barrôco, R.M., van Poucke, K., Bergervoet, J.H.W., de Veylder, L., Groot, S.P.C., Inze, D. \& Engler, G. 2005. The role of the cell cycle machinery in resumption of postembryonic development. Plant Physiology 137: 127-140.

Bashir, S., Wani, A.A. \& Irshad,A.N. 2013. Studies on mutagenic effectiveness and efficiency in fenugreek (Trigonella foenumgraecum L.). African Journal of Biotechnology 12(18): 2437-2440.

Begum, T. \& Dasgupta, T. 2010. A comparison of the effects of physical and chemical mutagens in sesame (Sesamum indicum L.). Genetics and Molecular Biology 33(4): 1-6.

Brandle, J.E.,Starratt,A.N. \& Gijzen, M. 1998. Stevia rebaudiana: Its biological, chemical and agricultural properties. Canadian Journal of Plant Science 78: 527-536.

Cramer, B. \& Ikan, R. 1987. Progress in the chemistry and properties of rebaudiosides. In Developments in Sweeteners New York, edited by Grenby, T.H. Elsevier. pp. 45-48.

Desai, R.M. \& Bhatia, C.R. 1975. Mutagenicity of N-methyl$\mathrm{N}$-nitrosourea and N-ethyI-N-nitrosourea in durum wheat. Mutation Research 27: 119-121.

Fousová, S., Velemínský, J., Gichner, T. \& Pokorny, V. 1974. DNA synthesis during the early stage of germination in the barley embryo meristems and its inhibition by N-methyl-Nnitrosourea. Biologia Plantarum 16(3): 168-173.

Gaul, H. 1970. Mutagen effects observable in the first generation. Manual on mutation breeding. International Atomic Energy Agency, Vienna 119: 85-89.

Geuns, J.M.C. 2003. Stevioside. Phytochemistry 64: 913-921.

Goettemoeller, J. \& Ching, A. 1999. Seed germination in Stevia rebaudiana. In Perspectives on New Crops and New Uses, edited by Janick, J. Alexandria: ASHS Press. pp. 510-511.

Hoffman, T., Schmidt, J.S., Zheng, X. \& Bent, A.F. 1999. Isolation of ethylene-insensitive soybean mutants that are altered in pathogen susceptibility and gene for gene disease resistance. Plant Physiology 119: 935-949.

Hofmann, N.R. 2009. OWL1 is a phytochrome a signaling component dedicated to the very low fluence response. The Plant Cell 21(10): 2985.

Hudson, K. 2012. Soybean oil-quality variants identified by large scale mutagenesis. International Journal of Agronomy 2012: 1-7.

Jovtcher, G., Menke, M. \& Schubert, I. 2001. The comet assay detects adaptation to MNU-induced DNA damage in barley. Mutation Research 493: 95-100.
Kallio, M. \& Lahdetie, J. 1995. Early G1 in the male rat meiotic cycle is hypersensitive to $\mathrm{N}$-methyl-N-nitrosourea induced micronucleus formation. Mutagenesis 10(4): 279-285.

Khan, M.H. \& Tyagi, S.D. 2010. Induced morphological mutants in soybean (Glycine max (L.) Merrill). Frontiers of Agriculture in China 4(2): 175-180.

Kozgar, M.I. 2014. Mutation Breeding in Chickpea: Prespectives and Prospects for Food Security. Berlin: Walter de Gruyter $\mathrm{GmbH}$ and $\mathrm{Co}$

Kumar, G. \& Yadav, R.S. 2010. EMS induced genomic disorders in sesame (Sesamum indicum L.). Romanian Journal of Biology - Plant Biology 55(2): 97-104.

Kurowska,M.,Labocha-Pawłowska,A., Gnizda,D.,Maluszynski, M. \& Szarejko, I. 2012. Molecular analysis of point mutations in a barley genome exposed to MNU and gamma rays. Mutation Research 738-739: 52-70.

Leitao, J.M. 2012. Chemical mutagenesis. In Plant Mutation Breeding and Biotechnology, edited by Shu, Q.Y., Forster, B.P. \& Nakagawa, H. Wallingford: CABI. pp. 135-158.

Luckett, D.J. 1989. Colchicine mutagenesis is associated with substantial heritable variation in cotton. Euphytica 42: 177-182.

Mohamad, O., Abdullateef, A.R., Lyena Watty Zuraine, A. \& Muhsin, M. 2012. Stevia breeding for higher productivity and level of Rebaudioside A. Genes and Genetic Systems 87(6): 395.

Para, A. \& Sundås-Larsson, A. 2003. The pleiotropic mutation darl affects plant architecture in Arabidopsis thaliana. Developmental Biology 254: 215-225.

Rai, S.P. \& Kumar, S. 2001. A tricotyledonous seedling mutant with Mendelian inheritance in periwinkle Catharanthus roseus. Journal of Medicinal and Aromatic Plant Science 22: 267-268.

Ramchander, S., Ushakumari, R. \& Arumugam Pillai, M. 2015. Lethal dose fixation and sensitivity of rice to gamma irradiation. Indian Journal of Agricultural Research 49(1): 24-31.

Ravichandran, V. \& Jayakumar, S. 2014. Effect of gamma rays on quantitative traits of sesame (Sesamum indicum L.) in M1 generation. International Journal of Advanced Research 2(8): 593-597.

Satoh, H., Matsusaka, H. \& Kumamaru, T. 2010. Use of $\mathrm{N}$-methyl-N-nitrosourea treatment of fertilized egg cells for saturation mutagenesis of rice. Breeding Science 60: 475-485.

Satoh, H. \& Omura, T. 1979. Induction of mutation by the treatment of fertilized egg cell with N-methyl-IV-nitrosourea in rice. Journal of the Faculty of Agriculture, Kyushu University 24(2.3): 165-174.

Schwontkowski, D. 1993. Herbs of the Amazon: Traditional and Common Uses. Utah: Science Student Brain Trust Publishing.

Sebastian, S.A., Fader, G.M., Ulrich, J.F., Forney, D.R. \& Chaleff, R.S. 1989. Semi-dominant soybean mutation for resistance to sulfonylurea herbicides. Crop Science 29(6): 1403-1408.

Singh, S.D. \& Rao, G.P. 2005. Stevia: The herbal sugar of $21^{\text {st }}$ Century. Sugar Tech 7(1): 17-24.

Songsri, P., Suriharn, B., Sanitchon, J., Srisawangwong, S. \& Kesmala,T.2011.Effects of gamma radiation on germination and growth characteristics of physic nut (Jatropha curcas L.). Journal of Biological Sciences 11: 268-274.

Srivinas, T.R. \& Veerabadhiran, P. 2010. Efficiency and effectiveness of physical and chemical mutagens and their combination in inducing chlorophyll mutations in $\mathrm{M}_{2}$ generation of Lablab (Lablab purpureus (L.) Sweet var. typicus). Electronic Journal of Plant Breeding 1(4): 752-757. 
Tan, S.L., Muhammad Ghawas, M., Mohamad Najib, M.Y. \& Zawayi, M. 2008. Preliminary evaluation and selection of Stevia under Malaysian conditions. Journal of Tropical Agriculture and Food Science 36(2): 1-7.

Toskulkao, C., Chaturat, L., Temcharoen, P. \& Glinsukon, T. 1997. Acute toxicity of stevioside, a natural sweetener and its metabolite, steviol in several animal species. Drug Chemical and Toxicology 20: 31-44.

Vázquez-Ramos, J.M. \& de la Paz Sánchez, M. 2003. The cell cycle and seed germination. Seed Science Research 13: 113-130.

Xili, L., Chengjiany, B., Eryi, X., Reiming, S., Yuengming, W., Haodong, S. \& Zhiyian, H. 1992. Chronic oral toxicity and carcinogenic study of stevioside in rats. Food Chemical and Toxicology 30: 957-965.

Zulkarnain. 2004. The production of tetraploid Swainsona formosa by colchicines mutagenesis. Zuriat 15(1): 60-64.

Lyena Watty Zuraine Ahmad \& Norrizah Jaafar Sidik Faculty of Applied Sciences

Universiti Teknologi MARA

40450 Shah Alam, Selangor Darul Ehsan

Malaysia
Lyena Watty Zuraine Ahmad \& Zarina Zainuddin*

Kulliyyah of Science

International Islamic University Malaysia

25200 Kuantan, Pahang Darul Makmur

Malaysia

Mohamad Osman

Department of Crop Science

Faculty of Agriculture

Universiti Putra Malaysia

43400 UPM Serdang, Selangor Darul Ehsan

Malaysia

Azhar Mohamad

Agrotechnology and Bioscience Division

Malaysian Nuclear Agency

43000 Bangi, Selangor Darul Ehsan

Malaysia

*Corresponding author; email: zzarina@ iium.edu.my

Received: 2 April 2018

Accepted: 22 October 2018 